Article

\title{
The Diversity of Bitter Manioc (Manihot Esculenta Crantz) Cultivation in a Whitewater Amazonian Landscape
}

\author{
James A. Fraser \\ Department of Anthropology, University of Sussex, Falmer, Brighton, BN1 9SJ, UK; \\ E-Mail: james.angus.fraser@gmail.com
}

Received: 23 March 2010; in revised form: 9 April 2010 / Accepted: 13 April 2010 /

Published: 16 April 2010

\begin{abstract}
While bitter manioc has been one of the most important staple crops in the central Amazon for thousands of years, there have been few studies of its cultivation in the fertile whitewater landscapes of this region. Anthropological research on bitter manioc cultivation in the Amazon has focused almost exclusively on long-fallow shifting cultivation in marginal upland areas of low soil fertility. This has contributed to the persistence of the oversimplified notion that because bitter manioc is well adapted to infertile upland soils; it cannot yield well in alluvial and/or fertile soils. I hypothesized that bitter manioc cultivation would be well adapted to the fertile soils of the whitewater landscapes of the central Amazon because of the centrality of this crop to subsistence in this region. In this article, I examine one such whitewater landscape, the middle Madeira River, Amazonas, Brazil, where smallholders cultivate bitter manioc on fertile Amazonian Dark Earths (ADE) and floodplain soils, and on infertile Oxisols and Ultisols. In this region, cultivation on fertile soils tends to be short-cycled, characterised by short fallowing (0-6 years) and shorter cropping periods (5-12 months) with a predominance of low starch fast maturing "weak" landraces. By contrast, cultivation on infertile soils is normally long-cycled, characterised by longer fallows ( $>10$ years) and longer cropping periods (1-3 years) with a predominance of high starch slow maturing "strong" landraces. This diversity in bitter manioc cultivation systems (landraces, fallow periods, soils) demonstrates that Amazonian farmers have adapted bitter manioc cultivation to the specific characteristics of the landscapes that they inhabit. I conclude that contrary to earlier claims, there are no ecological limitations on growing bitter manioc in fertile soils, and therefore the cultivation of this crop in floodplain and ADE soils would have been possible in the pre-Columbian period.
\end{abstract}


Keywords: swidden cultivation; shifting cultivation; terra preta; Amazonian dark earths; manioc landrace diversity; floodplain; weak and strong landraces; historical ecology

\section{Introduction}

Manioc (Manihot esculenta Crantz) has been the single most important staple carbohydrate energy source to Amazonian peoples for thousands of years [1-6]. Manioc varieties are classified as either bitter or sweet, depending on cyanogenic glucoside content. Bitter varieties require detoxification for consumption, but yield well in poor, acid soils, have a high starch content, and are more resistant to pests and pathogens. Sweet varieties can be eaten roasted or boiled with no need for detoxification, but they are more vulnerable to attack from pathogens, insects and mammals, yield less starch and require better soils [7,8]. It has been argued that sweet manioc is more appropriate for more mobile groups and bitter manioc is more suited to sedentary populations [7]. The majority of people living in rural areas of the Brazilian Amazon today are sedentary and culturally inclined to consume manioc in the processed form farinha (toasted flour) which, combined with fish, forms their staple diet [9]. Bitter manioc - the most commonly cultivated of the two - is the staple in many parts of the Amazon basin, along the courses of the major rivers in Eastern, Central and Northwestern Amazonia and in the wider Neotropical lowlands (the Orinoco basin, the Guianas). There are some important exceptions to this pattern; in parts of Western Amazonia and on the Southern periphery; sweet manioc predominates. Sweet manioc is a staple throughout the headwaters of all the major southern tributaries, as well as the Solimões. Only the upper Negro River is an exception [4,5,10]. Recent research has confirmed that both sweet and bitter manioc evolved from a single domestication event of the wild subspecies Manihot esculenta subsp. flabellifolia in Southwestern Amazonia [11,12].

This article addresses the on-going controversy surrounding ecological limitations on bitter manioc cultivation in the Amazon basin. The notion that there are ecological limitations on manioc production can be traced to the theory of "Tropical Forest Culture" elaborated from the 1950's onwards by Julian Steward, Betty Meggers and colleagues [6,13-17]. In this form of environmental determinism, the highly infertile soils of the lowland Neotropics posed an insurmountable barrier to cultural evolution: "The periodic exhaustion of the soil by manioc produces a semi-nomadic tribal life" [17: p. 19]. In other words, shifting cultivation forces people to keep moving with their fields, and precludes the formation of sedentary, hierarchical societies. In the early 1980's however, Robert Carneiro's study of manioc cultivation by Kuikuru Indians in the upper Xingu region demonstrated that, far from being constrained by poor soils, the Kuikuru produce a reasonably comfortable surplus of manioc flour each year, enough to enable them to absorb even "catastrophic" losses of manioc plants [18]. He asserted that in pre-Columbian times, similar forms of manioc cultivation could have supported larger populations. Archaeological work has since revealed that settlements more than ten times the size of contemporary villages existed in the Upper Xingu region in the pre-European period [19-23].

Whitewater rivers carrying nutrient rich sediments originating in the Andes [24,25], are especially amenable to human inhabitation owing to their provision of fertile floodplain soils and a 
superabundance of aquatic protein [3,6,26,27]. Meggers recognized the potential of regions with whitewater floodplains to support larger populations, but she concluded that unpredictable flood regimes rendered their fertile soils too unstable to support cultural efflorescence and large sedentary occupations [6]. Donald Lathrap and later Anna Roosevelt both argued contra Meggers that intensive agriculture and fishing in whitewater landscapes could have supported the development of autochthonous Amazonian Chiefdoms [3,27,28]. Recent archaeological work has demonstrated the presence of large, sedentary occupations in central floodplain regions [29-33].

Despite her criticism of Meggers, Roosevelt endorsed Meggers' assertion of ecological limitations on agricultural potential of the Amazon terra firme, in the sense that "sustained yield intensive cultivation of major Amazonian tropical forest soils is not possible with aboriginal methods". [34: p. 79, my emphasis]. Furthermore, Roosevelt then inverts Meggers' theory of ecological limitation in the context of bitter manioc cultivation. Roosevelt argued that because bitter manioc is so well adapted to yield in highly weathered and nutrient poor Oxisols and Ultisols of the uplands that it cannot yield well in fertile and/or alluvial soils [34: pp. 119-139]. This ecological limitation thesis rests on two major claims. The first is that because manioc is highly adapted to conditions of seasonal drought and water conservation, it does not perform well in the humid soils of the floodplain [e.g., 35]. The second is that because manioc is adapted to produce calories in acid, aluminium-rich nutrient-poor soils, when planted in fertile soils the production of leaves and stems increases at the expense of the development of tuberous roots, thereby reducing calorie production. These notions lead to the assumption that bitter manioc is best suited to long fallow shifting cultivation on poor upland soils [36], and that maize would be the focus of cultivation in floodplain [6,34].

The majority of anthropological studies of bitter manioc farming in the Amazon have almost exclusively focused on long-fallow shifting cultivation in the poor soils of marginal upland environments, by surviving Amerindian populations [e.g., 18,37,38-44]. This is because social and cultural anthropologists tend to study Indians, who today usually live in peripheral areas where they have avoided the most destructive effects of European contact. These environments are located on the periphery of Amazonia (the Guianas, the Orinoco, the Upper Xingu and the Upper Negro). This research bias is largely owing to the fact that most extant Amerindian people have survived by virtue of their migration to remote interfluvial regions [45], or because they are trekking populations who have always kept to the uplands [46]. The pattern of small-scale Amerindian groups cultivating bitter manioc in upland interfluvial regions observed today is in a large part a post-conquest adaptation [45].

A good proportion of bitter manioc cultivation has taken place in the rich whitewater landscapes of the Central Amazon, which were among the most heavily populated environments during the late preColumbian period and are consequentially the areas with the largest (up to 50 ha or more) and most abundant Amazonian Dark Earth (ADE) sites [32,47,48]. ADE are fertile anthropogenic (man-made) soils, whose formation is a legacy of Amerindian settlement patterns, mostly during the late preColombian period (2000-500BP) [49-51]. Still highly fertile hundreds or several thousand years after formation, ADE are found today at archaeological sites throughout the Amazon basin [30,32,52,53]. Contemporary populations in the region do produce analogous soils, albeit at a much more limited scale [54-58]. The formation of ADE involves "biochar" wherein charred organic material is added to soils [59], along with the deposition of diverse organic refuse [58]. This initiates a set of biological and chemical processes that lead to increased soil organic matter, microbial activity, cation exchange 
capacity, $\mathrm{pH}$ and nutrient retention, all of which are beneficial for agriculture [60-62]. ADE are generally split into two classes, terra pretas, which formed at sites of habitation, and terras mulatas, the sites of agricultural fields. The genesis of terras pretas lies in different practices of waste disposal; the burning of diverse refuse including fish, turtle and animal bones, palm fronds and weeds. Over time, dark brown or black anthropic soils form. This has been termed the 'midden model' of ADE formation, the standard scientific explanation for the origin of these soils [63]. Terras mulatas, less well documented and therefore more contentious, are thought to have formed through intensive agriculture involving "cool" burning and mulching. This is the agricultural model of ADE formation [64]. These soils have been found adjacent to some terra preta sites. They are less nutrient rich and light brown or greyish in color [5].

ADE sites are the most durable evidence that there were large sedentary populations in these central whitewater regions in the late pre-Columbian period [31,52]. William Denevan argued that settlements located on the terra firme bluffs in whitewater regions would simultaneously cultivate fertile but unstable and limited floodplain zones and the terra firme bluff areas that were safe from flooding but located on (initially) infertile soils [65,66]. Denevan recognized that large-scale bluff settlements could not have been supported only by seasonal floodplain cultivation and so proposed a combined model. In Denevan's bluff model, people therefore would have pursued a dual strategy of floodplain (river and lake) and terra firme cultivation and resource use. Denevan contends that bluff cultivation would have been semi-permanent, intensive with nutrient additions and short fallowing and could have created terra mulata [65-68]. Denevan's bluff model strengthens Lathrap's earlier argument by answering Meggers' contention that the floodplain alone is too unstable an environment to support larger settlements [69]. While Denevan's model is persuasive, studies of manioc cultivation in the floodplain are scarce [but see 70,71], and "evidence for intensive agriculture [on ADE] is largely inferential" [65: p. 113].

This article aims to contribute to the on-going debate surrounding ecological limitations in Amazonia by addressing the question of whether productive bitter manioc cultivation is possible in richer soils. Given that bitter manioc cultivation has long been central to subsistence in rich whitewater landscapes that feature fertile floodplain and ADE soils, as well as infertile Oxisols and Ultisols, I hypothesized that we should expect to find bitter manioc landraces and cropping systems that are adapted to cultivation in both fertile and infertile soils in these regions. The purpose of this article is to begin to fill the knowledge gap left by the lack of studies of traditional agriculture on fertile soils. The first studies that described bitter manioc cultivation in ADE appeared to support the second claim of the ecological limitation thesis. In the Brazilian Amazon, farmers reportedly claimed that while stems and foliage grow vigorously, tuber development is poor [72-78]. As I have argued elsewhere, the conclusions of these studies were premature, owing to their being conducted in regions where historical ecology has constrained agriculture (e.g., the Lower Negro), or in peri-urban regions with roads and commercial agriculture (the middle Amazon near Manaus and Itacoatiara) [47,48].

This article focuses on the middle Madeira River, Amazonas State, Brazil. Today it is inhabited by Caboclos, a people of diverse and heterogeneous origins that emerged through the process of European conquest of the Amazon and subsequent migrations driven by the extraction of forest products [79]. Bitter manioc is the primary staple source of carbohydrates for Caboclos living traditionally in rural areas of Amazonia, and the sale of manioc flour (farinha) is often an important source of income for 
them [9]. On the middle Madeira, market access is restricted because it is distant from the nearest large cities, Manaus and Porto Velho, and currently has no roads linking it to them. The major economic actors are large ferries travelling up and down the river linking these two cities. Traditional forms of horticulture are still predominant in the region. Caboclos have appropriated the major pre-Columbian modes of subsistence, and some of the skills associated with them that were practiced by Amerindian peoples. It is in such subsistence activities, primarily the cultivation of bitter manioc and the practices of fishing and hunting, but also in the cultivation of agroforests and kitchen gardens, and the extraction of forest products, that there is most continuity between post and pre-Columbian lifeways. The middle Madeira is a whitewater landscape with wide floodplains, abundant bluff-edge ADE sites, with Oxisols and Ultisols forming the terra firme background soils. Bitter manioc cultivation takes place in all of these soil types. The region therefore provides a perfect setting to investigate bitter manioc cultivation in different ecological contexts.

\section{Materials and Methods}

The research presented here draws on doctoral fieldwork carried out on the Middle Madeira River between September 2006 and March 2008 [47]. The initial stage of research was ethnographic, using the qualitative methods of participant observation and open-ended interviews. During this stage it emerged that locals divide bitter manioc landraces into two categories, "strong" and "weak" according to the suitability of particular sets of genetic traits to cultivation in different ecological contexts. This is described in detail in section three. The second stage of research was quantitative, using novel methods derived from ethnography. The remainder of this section outlines how locations and individuals were selected, and the methods through which agricultural systems were quantified. The results of the quantitative study are presented in section four.

\subsection{Quantitative Methods}

In order to measure the distribution of different landraces in different soil types, it was necessary to calculate the proportion of each field occupied by each landrace. Farmers normally recalled the relative proportions of the landraces present in a field in terms of the numbers of bundles of each landrace that they had planted there. From these figures, proportions of each landrace in a total field were calculated. For example, if a farmer said he had planted 2 bundles of Jabuti, 4 of Aruari, 1 of Tartaruga and 1 of Arroz in his field, the landrace areas would be 0.25 Jabuti, 0.5 Aruari, 0.125 Tartaruga and 0.125 Arroz (total $=1$ ). In order to account for different field sizes, the landrace areas in each field were then multiplied by the size of the field in fractions of a hectare. Fields range from 0.25 hectares up to 2 hectares. The sum of the areas for each landrace in each soil type was then divided by the total area of fields in that soil type, to give the Landrace Coverage Index for that type of soil. Hence,

$$
l c=\frac{\sum l \times f s i}{t f a}
$$

where $l c$ is landrace coverage, $l$ is the proportion of a field occupied by landrace $x, f_{s i} i$ is field size and $t f a$ is total field area (the sum of the area of all the fields in a particular soil type). 
On the middle Madeira River, local farmers categorise bitter manioc landraces in terms of their being stronger or weaker in relation to one another (see Section 3). In order to quantify this, farmers were asked to rank the landraces they plant starting with the weakest and ending with the strongest. Their answers were placed along an ordinal scale (from 1, the weakest, up to the strongest). The mean of all of the scores for a landrace was then used as an overall Landrace Strength Index for that landrace. Farmers were asked to give the approximate size of each field in fractions of a hectare, and the age of the fallow that it had been cleared from. Data on seasonality was collected during the final stages of research and it was therefore not possible to include the entire sample. Data on yields were collected only from farmers who had recorded how many sacks of manioc flour a particular field had yielded $(n=34)$.

\subsection{Selection of Locations and Individuals}

Quantitative data was collected in six localities, four in the terra firme, and two in the floodplain (Figure 1, Table 1). The terra firme localities were selected from the twenty or so communities visited in the initial period of research. The four localities, (1) Barro Alto, (2) Barriera do Capanã and Boa Vista, (3) Monte Sião, Monte Orebe and Água Azul, and (4) Vista Alegre, were selected because they had the most bitter manioc being planted in ADE, and therefore provided the best locations in which to compare cultivation in different kinds of soil. At these localities, all farmers with bitter manioc fields in $\mathrm{ADE}$ were interviewed, along with equivalent numbers of other farmers planting bitter manioc in Oxisols and Ultisols, including those who had fields in more than one kind of soil. Ideally, floodplain farmers resident in the same communities as terra firme farmers would have been selected for comparison. This was not possible, because (at least in all the 24 communities visited) most farmers resident in communities located on terra firme bluffs invariably plant bitter manioc on terra firme soils, generally preferring to plant other crops in the floodplain if they have access to it. Two floodplain localities, each spanning several communities, were selected for fieldwork. The first, known as the Água Azul floodplain, incorporates the communities of Paú Quemado (6 individuals) and Fortaleza (11 individuals), directly in front of Barreira do Capanã and Boa Vista, and those few members of the terra firme communities Água Azul, Monte Orebe and Monte Sião (7 individuals) who plant in the floodplain. The second locality is formed from members of three neighbouring communities (Verdum, Amparo and Delicia) located on the high floodplain downstream from Manicoré which lies between lake Genipapo, and the Madeira River main channel, opposite the mouth of the River Atininga (Figure 1, Table 1). These communities were selected because they are among the longest established and most well populated floodplain areas of the municipality of Manicoré. In the floodplain communities, all farmers who had fields and were present at the time of the research were interviewed. 
Figure 1. Map of the middle Madeira River, Amazonas, Brazil with the locations of the 12 communities where quantitative data on manioc cultivation was gathered. The location of the middle Madeira River in wider Amazonia is inset in the bottom right hand corner. Map drawn by Victoria Frausin.

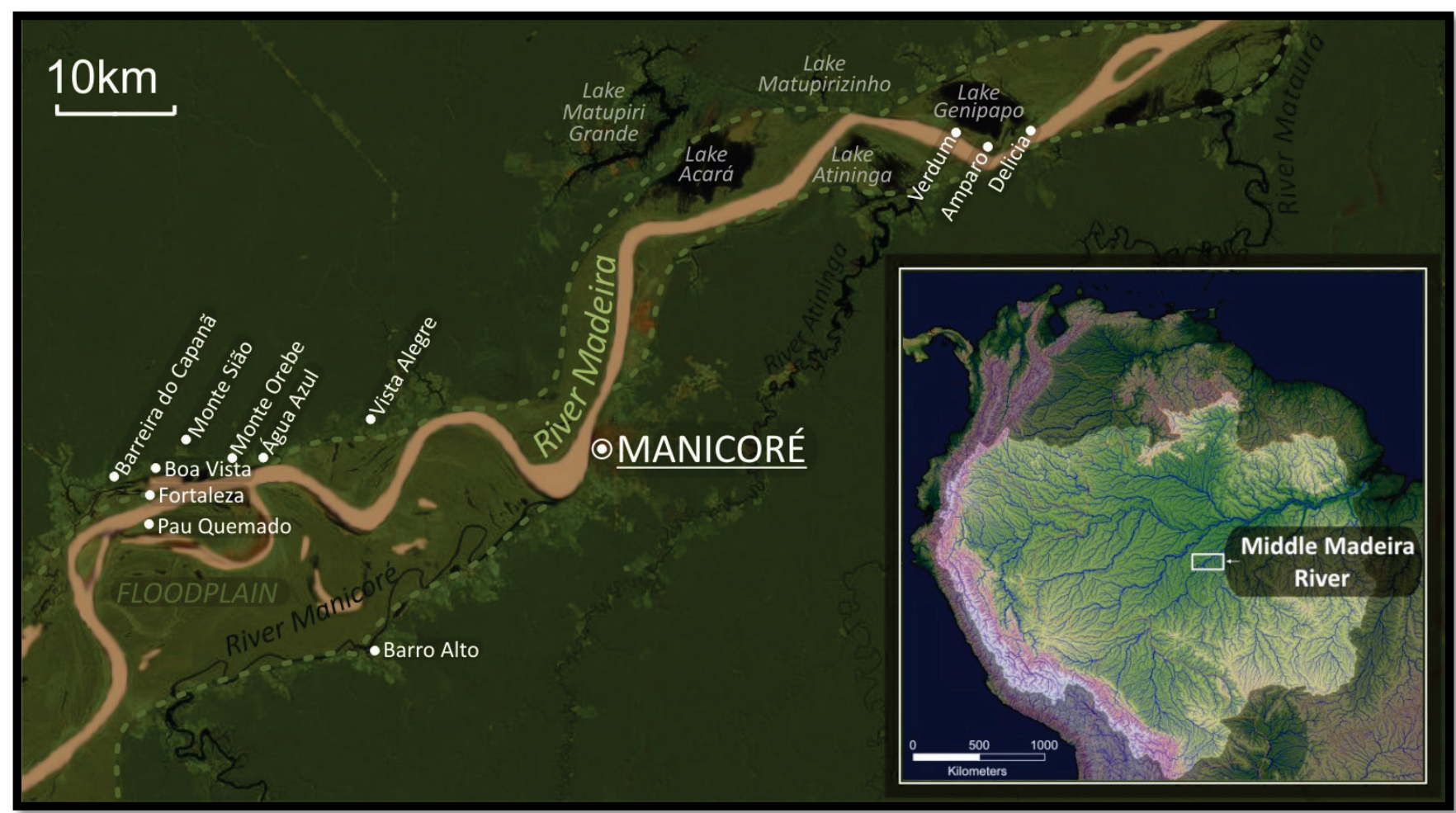

Table 1. Manioc dataset: Communities, number of informants $(n=)$ that contributed to strength index, and number of bitter manioc fields in each kind of soil.

\begin{tabular}{cccccc}
\hline Localities: & $\begin{array}{c}\text { Strength } \\
\text { Index }\end{array}$ & $\begin{array}{c}\text { Ultisols } \\
\text { Number of } \\
\text { Fields }\end{array}$ & $\begin{array}{c}\text { Oxisols } \\
\text { Number of } \\
\text { Fields }\end{array}$ & $\begin{array}{c}\text { Number of } \\
\text { Fields }\end{array}$ & $\begin{array}{c}\text { Number of } \\
\text { Fields }\end{array}$ \\
\hline Barro Alto & 35 & 25 & 33 & 36 & \\
Barreira do Capanã & 24 & 12 & 11 & 17 & \\
Água Azul, Monte Orebe, & & & & & \\
Monte Sião & 9 & 8 & 8 & 8 & \\
Vista Alegre & 19 & 10 & 12 & 10 & 24 \\
Água Azul floodplain & 22 & & & & 35 \\
Lake Genipapo floodplain & 30 & & & $\mathbf{7 1}$ & $\mathbf{5 9}$ \\
Total & $\mathbf{1 3 9}$ & $\mathbf{5 5}$ & $\mathbf{6 4}$ & & \\
\hline
\end{tabular}

\section{Strong and Weak Bitter Manioc}

Caboclo farmers on the middle Madeira use the terms "weak" (fraca) and "strong" (forte) to distinguish low starch fast maturing landraces from high starch slow maturing landraces. These terms essentially refer to the suitability of two opposing loci of genetic traits for cultivation in different ecological contexts. They express the rate of maturation and the suitability to different soils and 
different fallow ages associated with different bitter manioc landraces. Weak landraces often have a directly traceable origin in the floodplain and are fast maturing, harvestable as little as five months after planting, but they tend to have a higher water content that results in less starch production. They are also more likely to rot, or not soften in water if left in the ground for longer than a certain period of time. The characteristics exhibited by weak landraces strongly suggest a floodplain origin (fast maturing, fast seeding, but not long lasting in the ground), as these are traits that serve well in the floodplain. It is possible that having come from the floodplain these landraces are more capable of taking advantage of the greater nutrient levels in ADE. These landraces are also associated with short fallowing and short cropping cultivation. They are said to be more suited to intensive cultivation in more fertile soils (ADE/floodplain). By contrast, strong landraces are slow maturing, but produce more starch and less water, and therefore yield greater amounts of manioc flour when processed. Strong landraces resist rotting for longer periods and are the most durable in the land (lasting up to four years in some cases). They are said to be better suited to longer cropping cycles, long fallow cultivation in less fertile soils (Oxisols/Ultisols). Rather than a landrace being either weak or strong, farmers describe each landrace as being weaker or stronger than other landraces (Table 2).

On the terra firme, bitter manioc landraces and their degree of strength or weakness are not associated just with different soil types, but with short fallow or long fallow cultivation in those soil types. Farmers often stated that weak manioc is suited to "weak soils", and strong manioc is suited to "strong soils". The strength of a soil is determined by the age of fallow growing on it. Therefore, weak manioc is said to be best suited to cultivation in areas cut from young fallow. It is only normally cultivated in areas cut from young fallows on ADE, because young fallows in other soils do not yield well. Still, if young fallow is cleared on Oxisols and Ultisols, farmers claim that it is best to plant weak manioc. Strong varieties are said to be best suited to planting in fields cleared from old fallow or primary forest, which are indicators of "strong land".

Farmers in the floodplain also used the terms weak and strong to describe the landraces they plant there. This is interesting because the literature tends to assume that all floodplain landraces are necessarily low starch fast maturing [80]. This research found however that there are a number of floodplain landraces that are considered "strong" or high starch slow maturing. These do not appear to have come from the terra firme, but are said to come from the floodplain itself. Local farmers divide the floodplain into three zones, the main channel, or vazante, the high floodplain, or restinga, and the lake backswamp area, or cacaia. Weak manioc is said to be better suited to lower areas of the cacaia and in the vazante. Farmers tended to plant the weakest landraces closest to the main channel or lake (which are both the most humid and first places to flood). They said that they did this for two reasons. The first was that the area closest to the water would flood first and therefore needs to be harvested first, hence they planted the fastest maturing landraces. Secondly, these fast maturing landraces were said to be most able to resist the greater humidity of these soils. These lower areas of the floodplain are of higher fertility because they receive a wash of nutrients in the yearly flood. People said that strong manioc is best planted "em cima da terra" (at the top of the land), in the restinga and in the higher ground of the cacaia and vazante. These areas may only flood every 5-10 years, and so can be planted with slower maturing manioc.

It would appear therefore that in the floodplain, strong and weak manioc, rather than being associated with different soil types and fallow ages as they are on the terra firme, are instead seen as 
being best suited to different floodplain zones, and associated differences in flood-regime and soil fertility. The fact that the lower soils are generally more fertile as they receive a wash of nutrients from floodwater, and that these are the ones where weak manioc are seen to be more suitable, provides an interesting parallel with their association with ADE on the terra firme. Likewise, the association of strong landraces in the floodplain with the less fertile high ground provides an interesting parallel with the perceived suitability of strong landraces to cultivation in soils of lower fertility with longer fallows on the terra firme. A key similarity between the floodplain and terra firme is the perception that weak and strong landraces are suited to different agro-ecological contexts. The key difference is the flood regime, and the selective pressure it must exert for fast maturing landraces and the ability to resist waterlogging. Farmers recognise traits in floodplain bitter manioc landraces that would appear to be unique adaptations to this environment. The tuberous roots of certain landraces, it is said, can remain underwater for several days without rotting in times of flooding. Interestingly, some farmers said weak manioc is more able to resist waterlogging because the root itself is more humid.

Table 2. Characteristics of weak and strong manioc landraces and their suitability to different ecological contexts according to farmers along the middle Madeira River, in the municipality of Manicoré, Amazonas state, Brazil.

\begin{tabular}{|c|c|c|}
\hline Characteristic & $\begin{array}{c}\text { Weak Manioc } \\
\text { Low-Starch Fast-Maturing }\end{array}$ & $\begin{array}{c}\text { Strong Manioc } \\
\text { High-Starch Slow-Maturing }\end{array}$ \\
\hline Maturation & Faster & Slower \\
\hline Starch production & Less (more water) & More (less water) \\
\hline Resistance to rotting & $\begin{array}{c}\text { Lower (6 months to } 1.5 \\
\text { years) }\end{array}$ & $\begin{array}{l}\text { Higher (up to } 3 \text { or } 4 \text { years in } \\
\text { the ground) }\end{array}$ \\
\hline Softening in water & Only in earlier stages & Softens even after years \\
\hline $\begin{array}{l}\text { Suitability to fallow age } \\
\text { (terra firme only) }\end{array}$ & Earlier successional stages & Later successional stages \\
\hline $\begin{array}{l}\text { Lengths of cropping- } \\
\text { fallowing cycles }\end{array}$ & $\begin{array}{c}\text { Shorter fallowing, shorter } \\
\text { cropping }\end{array}$ & $\begin{array}{c}\text { Longer fallowing, longer } \\
\text { cropping }\end{array}$ \\
\hline Soil associations & ADE / Floodplain & Oxisol / Ultisol \\
\hline
\end{tabular}

\section{The Diversity of Bitter Manioc Cultivation Systems on the Middle Madeira}

This section presents and analyses quantitative data in order to determine whether there are divergent bitter manioc cultivation systems in different ecological contexts.

\subsection{Smaller Fields, Higher Yields}

The more productive nature of bitter manioc cultivation in more fertile soils is demonstrated by the comparison of field sizes and yields in ADE and the floodplain with those in Oxisols and Ultisols. There were significant differences between the field sizes in different soil types (Table 3). Mean field sizes in Oxisols and Ultisols are closer to a hectare, while those in the floodplain and ADE are closer to half a hectare in size. According to farmers, one reason for the smaller field size in more fertile kinds of soil is higher yields and greater weed pressure. Another reason could be that villages tend to be located near good soils and that local population density and land scarcity is higher in areas with 
fertile soils. Median yields are the same on ADE and in the floodplain, higher than those recorded on Oxisols and Ultisols (Table 4). In terms of caloric production, bitter manioc cultivation in ADE and the floodplain can theoretically support larger populations on smaller areas of land. Higher productivity may also contribute to smaller field sizes, because more tubers can be produced on smaller areas of land. However, smaller fields may be related to the fact that ADE and the floodplain are limited in extension compared to Oxisols and Ultisols, which are essentially unlimited.

Table 3. Manioc field sizes in different soil types along the middle Madeira River.

\begin{tabular}{cccccc}
\hline Soil & $\mathbf{n}=$ & Mean Size (ha) & Std Dev & Std. Error & Median Size (ha) \\
\hline Ultisol & 55 & 0.809 & 0.36 & 0.0485 & 1 \\
Oxisol & 64 & 1.012 & 0.455 & 0.0569 & 1 \\
ADE & 71 & 0.605 & 0.39 & 0.0462 & 0.5 \\
Floodplain & 59 & 0.631 & 0.326 & 0.0425 & 0.5 \\
\hline
\end{tabular}

Table 4. Manioc yields in four types of soil. An average sack is equivalent to 60 kilos. Median is more reliable than mean because of some large outliers. Figures do not take into account starch production of individual landraces, nor do they take into account the age of the fallow vegetation, both of which affect yield. Figures taken from farmers who had accurately recorded (written down) the number of sacks of farinha they had processed from a particular field.

\begin{tabular}{ccccccc}
\hline Soil Type & $\mathbf{n =}$ & $\begin{array}{c}\text { Farinha sacks per } \\
\text { ha (Median) }\end{array}$ & $\begin{array}{c}\text { Median Manioc } \\
\text { Flour Production per } \\
\text { ha }\end{array}$ & $\begin{array}{c}\text { Mean } \\
\text { sacks }\end{array}$ & $\begin{array}{c}\text { SD } \\
\text { sacks }\end{array}$ & $\begin{array}{c}\text { SE } \\
\text { sacks }\end{array}$ \\
\hline Oxisol & 10 & 37.5 & $2,250 \mathrm{~kg} / \mathrm{ha}$ & 81 & 7.2 & 22.8 \\
Ultisol & 6 & 35 & $2,100 \mathrm{~kg} / \mathrm{ha}$ & 72 & 3.1 & 7.5 \\
ADE & 12 & 50 & $3,000 \mathrm{~kg} / \mathrm{ha}$ & 107 & 9.8 & 34.1 \\
Floodplain & 6 & 50 & $3,000 \mathrm{~kg} / \mathrm{ha}$ & 94 & 7.9 & 19.4 \\
\hline
\end{tabular}

While those farmers included in the yield estimates said they had kept a count of the number of sacks of manic flour harvested, these figures should be treated with caution, and certainly do not prove anything. What they do show is that bitter manioc planted in ADE does not yield less than other soil types as other commentators have claimed [74,76]. On the contrary, yields are probably better (Figure 2). What is clear is that these soils can give impressive yields under short fallow cultivation, which is impossible on Oxisols and Ultisols. 
Figure 2. Yields of certain bitter manioc landraces are better in ADE. The tuberous roots of landraces "Tartaruga," (left) harvested from ADE 7.5 months after planting at Monte Sião and "Pirarucu Branco" (right) harvested from ADE 16 months after planting at Barreira do Capanã. Photos by the author.
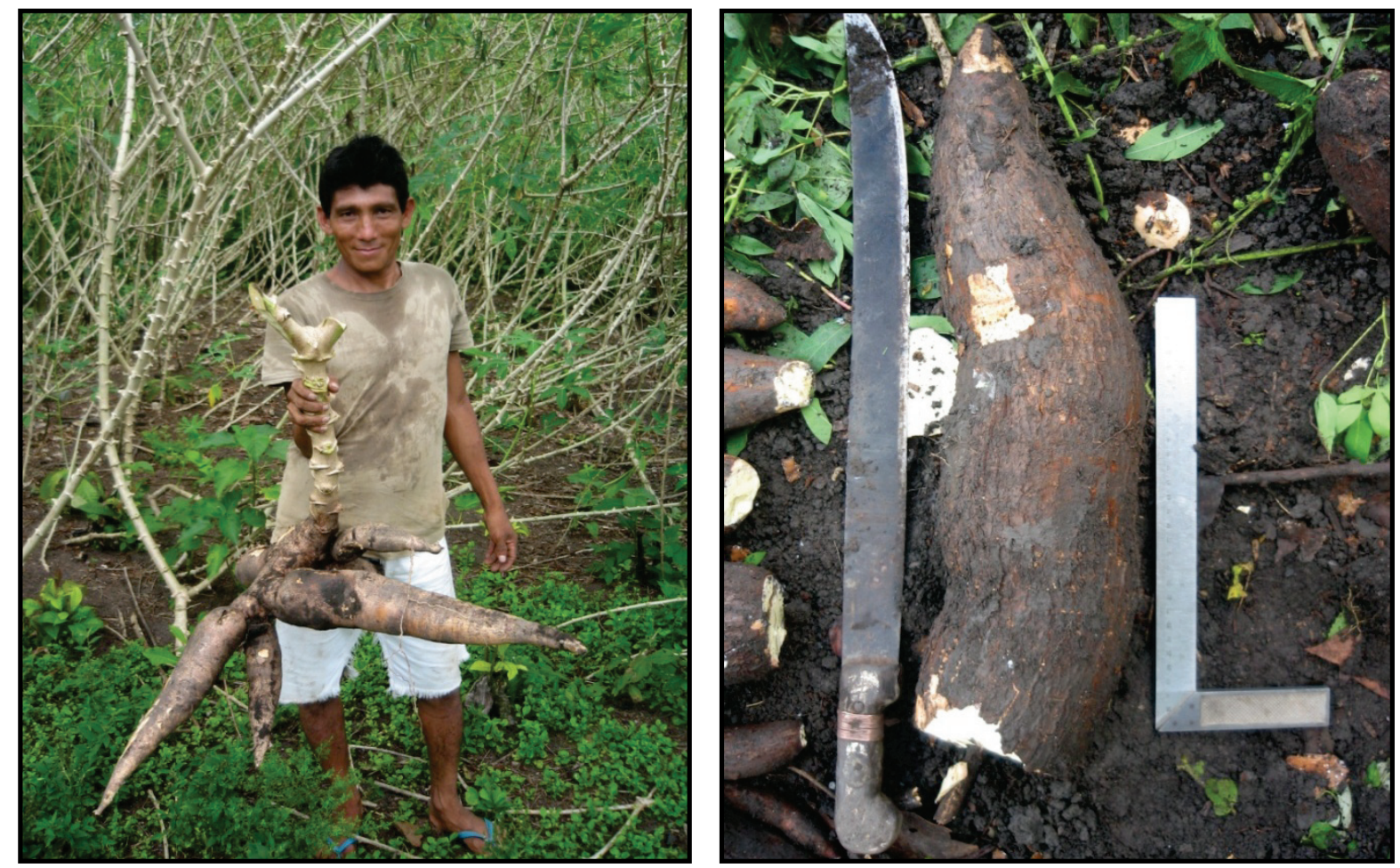

\subsection{Diversity of Bitter Manioc Landraces in Different Ecological Contexts}

Farmers cultivating Oxisols have the greatest preference for the stronger landraces Jabuti, Arroz and Roxinha-RM (Table 5, Figure 3-A). The prevalence of strong manioc is related to the fact that farmers believe that strong landraces perform better in these soils. There is significantly greater landrace coverage $(l c)$ of these three landraces in Oxisols when compared to ADE (Figure 4-BCD). Farmers planting in Ultisols also plant more of the stronger landraces Jabuti and Roxinha-RM (Table 5 , Figure 3-B). There is a significantly greater $l c$ of the strong landrace Jabuti in Ultisols when compared to ADE (Figure 4-B). But the presence of Tartaruga in large quantities in Ultisol fields means that landrace assemblages in Ultisols do not contain as much strong manioc as Oxisols. This can be explained in part by the fact that some 25 (nearly half) of the 55 Ultisol fields are from the community Barro Alto, where the Ultisols lie close behind the community, and population pressure has led to more intensive cultivation on these soils than on the more distant Oxisols [81]. On non-anthropogenic soils of the terra firme, farmers will plant more weak bitter manioc if fallow vegetation is still young, as they believe that when soil is weak, weak manioc yields better than strong manioc. More Ultisol fields in the study are located in younger fallow than fields on Oxisols (Table 6, Figure 5). This is an effect of the population pressure at Barro Alto, rather than a general tendency for farmers to clear younger fallow on Ultisols, which was not observed.

In ADE fields the landrace Tartargua is most predominant. It is considered to be weak by farmers, and most probably originates in the floodplain (Table 5, Figure 3-C). The mean $l c$ of Tartargua is 
significantly greater in ADE than in any other type of soil (Figure 4-A). Local people at all locations recognized this landrace as being most suited to ADE. They also claim that other floodplain landraces, such as Pirarucu Branco, Pirarucu Amerelo, Glaí and Roxinha Branca yield well in ADE, and this is apparent in their greater presence in ADE than in Oxisols or Ultisols (Table 5, Figure 3-ABC). Conversely, the stronger landraces Jabuti, Arroz and Roxinha-RM, that are most predominant in Oxisols and Ultisols have a significantly lower mean $l c$ in ADE when compared to Oxisols, although when ADE is compared to Ultisols only Jabuti has a significantly lower mean lc (Figure 4-BCD). This is reflected in the frequent statement that strong manioc does not yield well in ADE. In fact, various individuals said that when landraces are planted in the wrong kind of soil, they tend to produce stems and leaves at the expense of tuberous roots. This would suggest that the reason that some researchers found that manioc does not yield well in ADE or the floodplain is related to the planting of landraces that are unsuitable to certain agro-ecological contexts, rather than any real "ecological limitation". The floodplain has its own set of landraces, most of which were absent from the terra firme, but those that were present, as noted above, were most predominant in ADE (Figure 3-CD, Table 5). The most predominant landrace in the floodplain was also Tartaruga, the same as in ADE. Farmers in the floodplain consider the most popular landraces to be weak, as with farmers cultivating ADE (Table 5, Figure 3-D).

Overall there is a clear tendency for the most predominant landraces to be strong in Oxisols and Ultisols and to be weak in ADE and floodplain soils (Figure 3). This shows that farmers have been selecting for certain traits that they have found to be adaptive in different ecological contexts. The fact that their local knowledge of the suitability of certain traits to planting in different ecological contexts is expressed through a local theory of strength and weakness means that it is likely that these processes of selection have been developed over several generations. The presence of such selective trajectories supports the notion that bitter manioc cultivation has been adapted to the affordances of both fertile and infertile soils in the Central Amazon. 
Table 5. Strength and Landrace Coverage for 55 Ultisol fields, 64 Oxisol fields, 71 ADE fields, and 59 floodplain fields along the middle Madeira River.

\begin{tabular}{|c|c|c|c|c|c|c|c|c|c|c|c|c|}
\hline \multirow[b]{2}{*}{ Landraces } & \multicolumn{2}{|c|}{ Strength } & \multicolumn{4}{|c|}{ Landrace Coverage } & \multirow[b]{2}{*}{$A D E$} & \multirow[b]{2}{*}{$n$} & \multirow[b]{2}{*}{$F P$} & \multirow[b]{2}{*}{$n$} & \multirow[b]{2}{*}{ Total } & \multirow[b]{2}{*}{$n$} \\
\hline & Str & $n$ & $U L$ & $n$ & $O X$ & $n$ & & & & & & \\
\hline Tartaruga & 1.6 & 81 & 0.155 & 30 & 0.046 & 19 & 0.419 & 53 & 0.215 & 32 & 0.835 & 204 \\
\hline Roxinha-RM & 3.2 & 29 & 0.243 & 28 & 0.241 & 35 & 0.148 & 18 & & & 0.632 & 149 \\
\hline Jabuti & 5.1 & 47 & 0.260 & 24 & 0.236 & 34 & 0.044 & 15 & & & 0.540 & 159 \\
\hline Arroz & 4.4 & 48 & 0.093 & 19 & 0.195 & 43 & 0.067 & 22 & & & 0.355 & 138 \\
\hline Aruari & 2.9 & 27 & 0.076 & 20 & 0.112 & 27 & 0.027 & 9 & & & 0.215 & 70 \\
\hline Pirarucu Amarelo & 1.4 & 21 & 0.024 & 6 & 0.018 & 7 & 0.051 & 10 & 0.08 & 10 & 0.173 & 49 \\
\hline Pirarucu Branco & 3.0 & 33 & 0.013 & 7 & 0.015 & 8 & 0.088 & 14 & 0.044 & 9 & 0.160 & 38 \\
\hline Sempre Serve & 1.3 & 26 & & & & & & & 0.149 & 26 & 0.149 & 26 \\
\hline Curuça & 3.4 & 27 & & & & & & & 0.149 & 27 & 0.149 & 27 \\
\hline Maria Dias & 3.0 & 3 & & & & & & & 0.123 & 4 & 0.123 & 12 \\
\hline Glai & 2.1 & 13 & 0.006 & 3 & 0.01 & 4 & 0.021 & 8 & 0.04 & 6 & 0.077 & 33 \\
\hline Roxinha-BC & 4.9 & 8 & 0.054 & 9 & 0.015 & 6 & 0.003 & 2 & & & 0.072 & 39 \\
\hline Jijú & 1.9 & 14 & 0.017 & 5 & 0.047 & 11 & 0.003 & 3 & & & 0.067 & 19 \\
\hline Mãe Joana & 2.9 & 15 & & & & & & & 0.064 & 12 & 0.064 & 22 \\
\hline Roxinha Branca & 1.6 & 13 & 0.006 & 5 & 0.012 & 5 & 0.039 & 7 & & & 0.057 & 17 \\
\hline Olho Roxo & 2.2 & 5 & & & & & & & 0.052 & 9 & 0.052 & 9 \\
\hline Juvenal & 3.2 & 13 & & & & & & & 0.048 & 12 & 0.048 & 20 \\
\hline Amarelinha-VA & 3.0 & 2 & 0.002 & 2 & 0.015 & 4 & 0.019 & 2 & & & 0.036 & 20 \\
\hline Sara(nzal) & 4.9 & 7 & 0.003 & 3 & 0.019 & 6 & 0.012 & 8 & & & 0.034 & 17 \\
\hline Abidãozinho & 1.7 & 9 & & & & & & & 0.034 & 9 & 0.034 & 9 \\
\hline Vermelinha & 2.5 & 2 & & & & & & & 0.03 & 3 & 0.030 & 3 \\
\hline Manaus & -- & 0 & & & & & & & 0.03 & 1 & 0.030 & 1 \\
\hline Jararaca Branca & 1.8 & 4 & & & & & & & 0.03 & 1 & 0.030 & 1 \\
\hline Toazinha & 1.3 & 2 & & & & & & & 0.03 & 2 & 0.030 & 4 \\
\hline Amarelinha-BC & 2.0 & 2 & 0.028 & 7 & 0.001 & 1 & 0 & 0 & & & 0.029 & 8 \\
\hline Direitinha & 1.4 & 10 & & & & & & & 0.026 & 9 & 0.026 & 9 \\
\hline Beleza & 3.5 & 4 & & & & & & & 0.023 & 5 & 0.023 & 5 \\
\hline Japim & 2.0 & 1 & & & & & & & 0.02 & 1 & 0.020 & 1 \\
\hline Roxona-VA & 3.5 & 2 & 0.010 & 2 & 0 & 0 & 0.009 & 3 & & & 0.019 & 11 \\
\hline Piraiba & 1.8 & 5 & 0 & 0 & 0.005 & 3 & 0.012 & 3 & & & 0.017 & 8 \\
\hline Guia Roxa & 3.6 & 5 & 0 & 0 & 0.001 & 1 & 0.012 & 2 & & & 0.013 & 3 \\
\hline Jararaca Branca & 1.0 & 1 & & & & & & & 0.008 & 1 & 0.008 & 1 \\
\hline Roxona-BC & 3.7 & 3 & 0 & 1 & 0 & 0 & 0.006 & 4 & & & 0.006 & 5 \\
\hline Julio da Varzea & -- & 0 & 0 & 0 & 0 & 0 & 0.006 & 1 & & & 0.006 & 1 \\
\hline Manaus & 3.0 & 1 & 0.002 & 2 & 0 & 0 & 0.003 & 3 & & & 0.005 & 7 \\
\hline Caraulho & -- & 0 & 0 & 0 & 0.003 & 1 & 0.002 & 1 & & & 0.005 & 2 \\
\hline Vermelão & 3.0 & 1 & & & & & & & 0.004 & 1 & 0.004 & 1 \\
\hline Galhadinha & 4.0 & 1 & & & & & & & 0.003 & 1 & 0.003 & 1 \\
\hline Amerelona & 2.00 & 1 & 0 & 0 & 0 & 0 & 0.003 & 1 & & & 0.003 & 1 \\
\hline Expomani & -- & 0 & 0.002 & 1 & 0 & 0 & 0 & 0 & & & 0.002 & 1 \\
\hline Manauens & 1.0 & 1 & & & & & & & 0.002 & 1 & 0.002 & 3 \\
\hline Azolão & 8.0 & 1 & 0 & 0 & 0 & 1 & 0.001 & 1 & & & 0.001 & 2 \\
\hline Pacu & 4.0 & 1 & 0 & 0 & 0 & 0 & 0.001 & 1 & & & 0.001 & 1 \\
\hline Bonitinha-BA & -- & 0 & 0 & 0 & 0 & 0 & 0.001 & 2 & & & 0.001 & 4 \\
\hline Bonitinha-BC & 3.0 & 3 & 0 & 0 & 0 & 1 & 0 & 1 & & & 0.001 & 4 \\
\hline
\end{tabular}


Figure 3. Total Landrace Coverage and relative Strengths of the 15 bitter manioc varieties that are most predominant in 64 Oxisol fields (3-A), 55 Ultisol fields (3-B), 71 ADE fields (3-C), 59 floodplain fields (3-D) along the middle Madeira River.
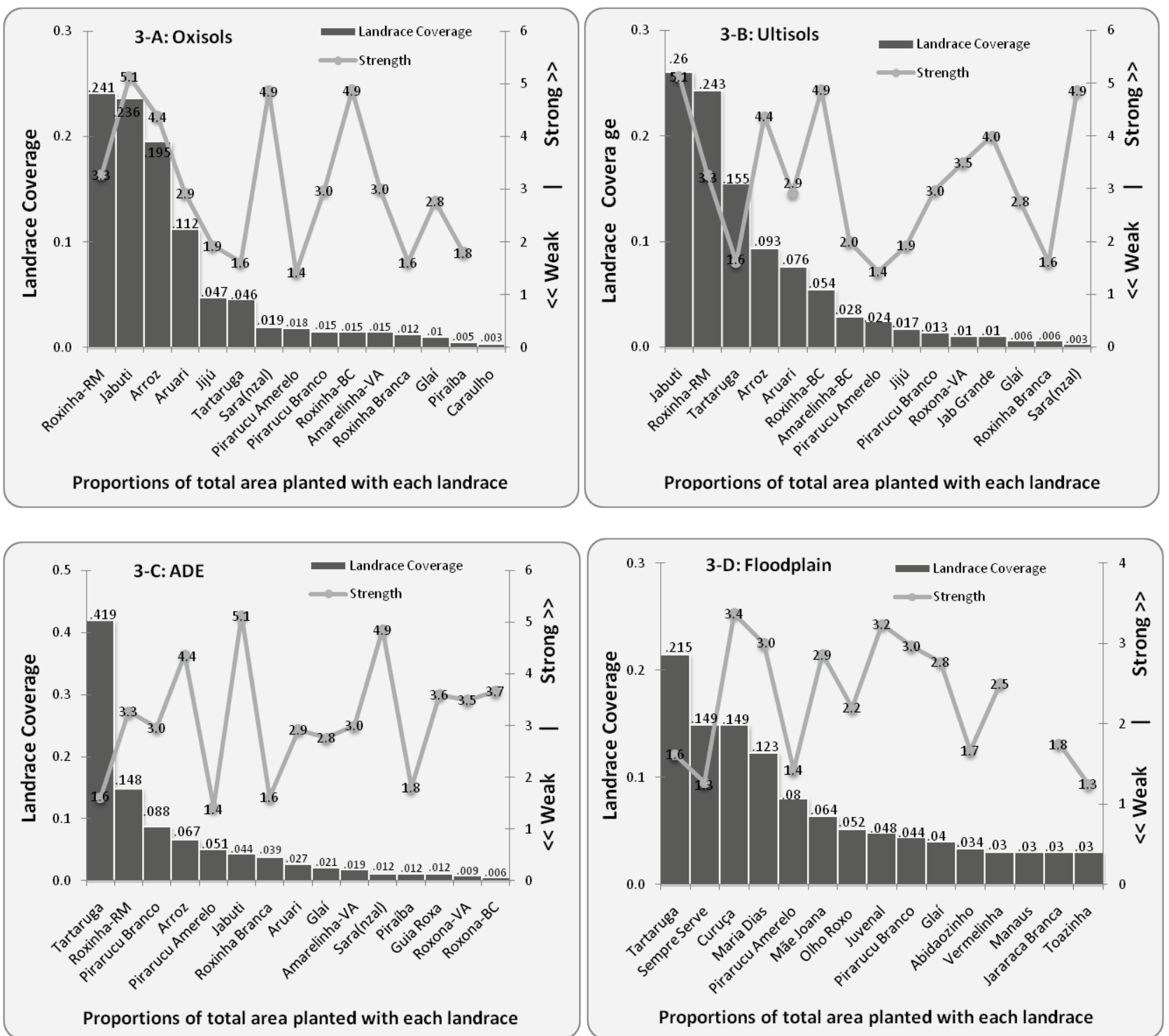
Figure 4. ANOVA comparing mean $l c$ for key landraces in different types of soil along the middle Madeira River. Letters indicate significantly different means based on Tukey's post-hoc test $(p<0.05)$. Vertical lines on each bar represent the standard error.
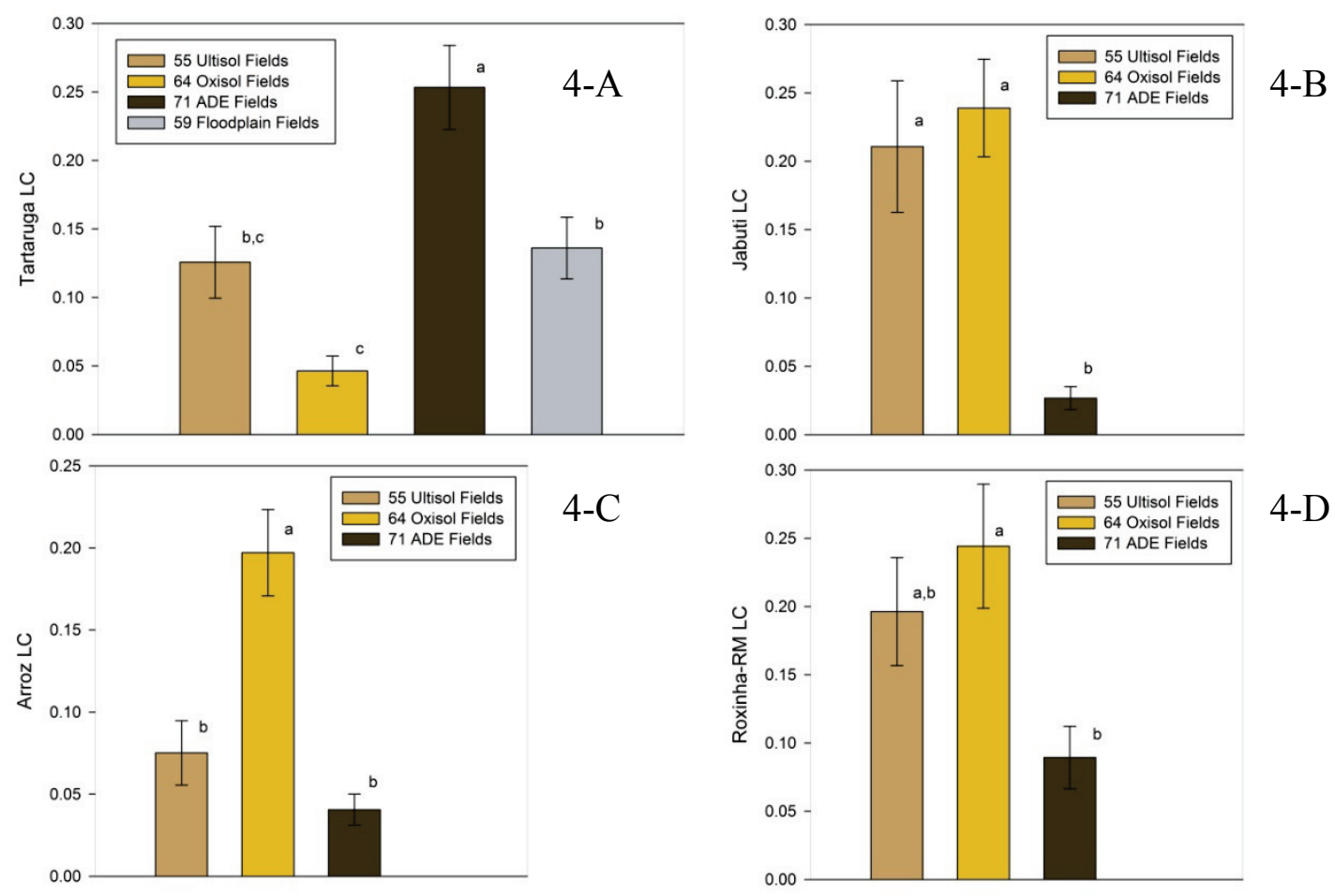

\subsection{Fallow Periods and Seasonality in Different Ecological Contexts}

There were significant differences in the ages of fallow cleared for fields in all of the four different types of soil (Table 6, Figure 5). Interestingly, this order of intensity of farming in terms of fallow lengths corresponds with the predominance of weak (fast maturing) and strong (slow maturing) bitter manioc varieties in the different soil types. The soil type with greatest proportion of weak manioc, is also the soil type with the lowest mean fallow age: the floodplain. This pattern continues, with proportions of weak manioc decreasing as fallow lengths increase. ADE is the most similar to the floodplain, with shorter fallows and more weak landraces than the other terra firme soil types. While the mean age of vegetation cleared is significantly different when every possible ANOVA comparison is made, the ADE-floodplain comparison was of weaker significance (Figure 5). Ultisol fields exhibit longer fallows and more strong landraces than $\mathrm{ADE}$, and finally Oxisols feature the longest fallows and greatest proportions of strong manioc. This shows that the prevalence of fast maturing or slow maturing landraces correlates with fallow ages as well as soil fertility, which provides more evidence for differentially adapted cultivation systems in the different soil types. The predominance of strong bitter manioc on Oxisols is also related to the fact that more old fallow/mature forest being cleared is located on these soils (Table 6, Figure 5). There is a widespread perception that strong manioc is best suited to old fallow or mature forest, as old fallow is an indicator of land which is strong because it has not been cultivated recently, i.e., it has had more time to recover its strength during the fallow. ADE fields tend to be located in younger fallow, and interviews with farmers indicate that manioc is harvested earlier on ADE, beginning as little as five to six months after planting. Fast maturing, 'weak' 
landraces would appear to better fit short-fallow cultivation, because their quicker maturation corresponds with shorter fallowing. Swidden cultivation practiced in ADE and in the floodplain is characterised by a predominance of weak landraces that are faster maturing, and so fit an intensive (smaller fields, shorter fallowing, shorter cropping periods) scenario. German also observed more intensive swidden cultivation on ADE on the lower Negro river [74: p. 326]. In at least five aspects $\mathrm{ADE}$ and floodplain cultivation display considerable similarity: $(i)$ a predominance of landraces that are considered weak, some of which are the same, (ii) shorter-cropping periods, (iii) shorter fallows, (iv) higher yields, and (v) smaller fields. This is significant because it shows similar adaptations in bitter manioc cultivation in the two fertile soils. Conversely, long fallow shifting cultivation in Oxisols and Ultisols is characterised by a predominance of strong landraces that are slower maturing, and so fit into a more extensive longer cropping, long fallow scenario.

Table 6. Descriptive statistics for ages of vegetation (in years) cleared in 59 floodplain, 71 ADE, 64 Oxisol, and 55 Ultisol fields along the middle Madeira River.

\begin{tabular}{cccccc}
\hline Soil & n= & Mean & Std. Dev & Std. Error & Median \\
\hline Ultisol & 55 & 13.164 & 8.082 & 1.09 & 12 \\
Oxisol & 64 & 21.344 & 15.533 & 1.942 & 15 \\
ADE & 71 & 6.458 & 6.839 & 0.812 & 4 \\
Floodplain & 59 & 1.593 & 4.039 & 0.526 & 0 \\
\hline
\end{tabular}

Figure 5. ANOVA comparing mean fallow age cleared in years in four types of soil along the middle Madeira River. Letters indicate significantly different means based on Tukey's post-hoc test $(p<0.05)$. Vertical lines on each bar represent the standard error.

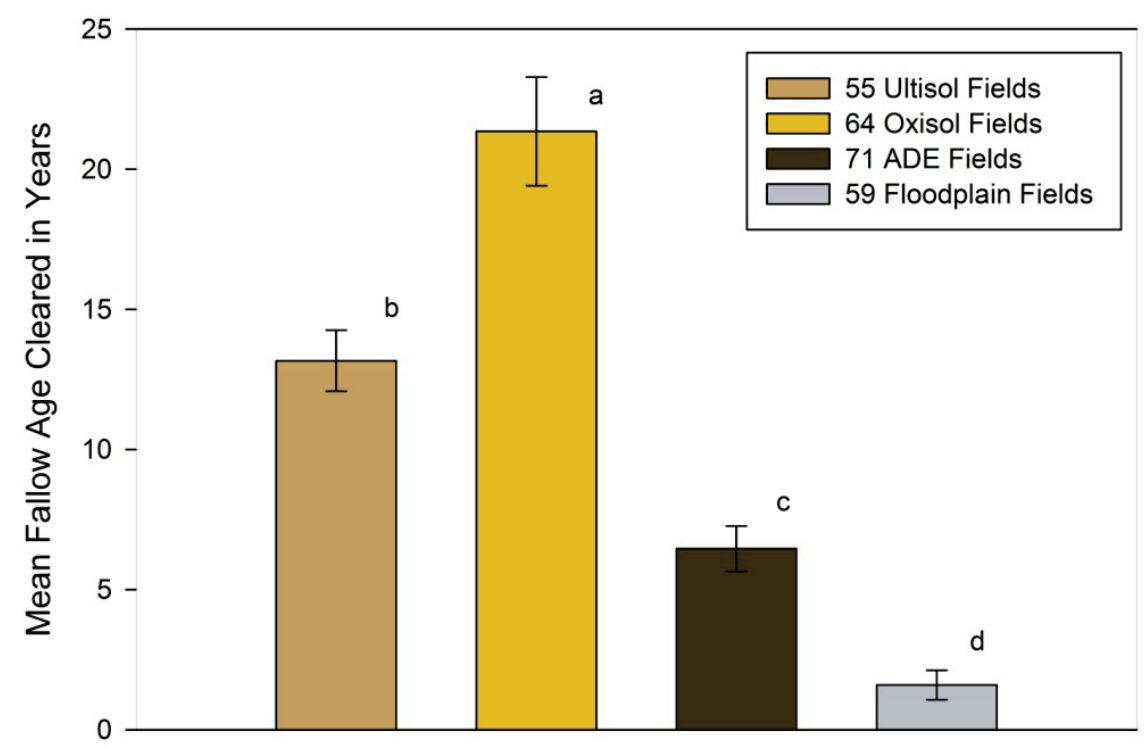

The months of planting vary among the different soil types (Figure 6). Most Oxisol and Ultisol fields are planted in September and October. This is typical of long-fallow shifting cultivation, where fields are cut in June, after the rains end, then left for a few months to dry, to allow for a hot burn. Oxisol and Ultisol fields need to be located in older fallow, because these soils are nutrient poor and are therefore more dependent on the burn to provide a nutrient flush. ADE fields are planted nearly 
throughout the year, with a three month break at the end of the year, which is precisely when most of the Oxisol and Ultisol fields are planted. Seasonal constraints are effectively removed by the fertility of ADE, owing to of the higher fertility of these soils they are not so dependent on the burn to provide a nutrient flush. This is something that German noted on the lower Negro River [72]. Fields can be planted all year round on ADE because young fallow can be cleared and burnt during a couple of rain free days. Some farmers explained how they capitalized on this, by planting manioc in January and February in order to harvest from July onwards. They do this to take advantage of the higher prices for manioc flour because of the seasonally lower production during this period precisely because much of the bitter manioc planted in Oxisols and Ultisols has been harvested by this point. Fields in the floodplain tended to be planted from May to August, as this is when the rainy-season ends and the water level is descending (Figure 6).

Figure 6. Month of planting for 103 bitter manioc fields in 4 types of soil on the middle Madeira River in the Municipality of Manicoré, Amazonas State, Brazil.

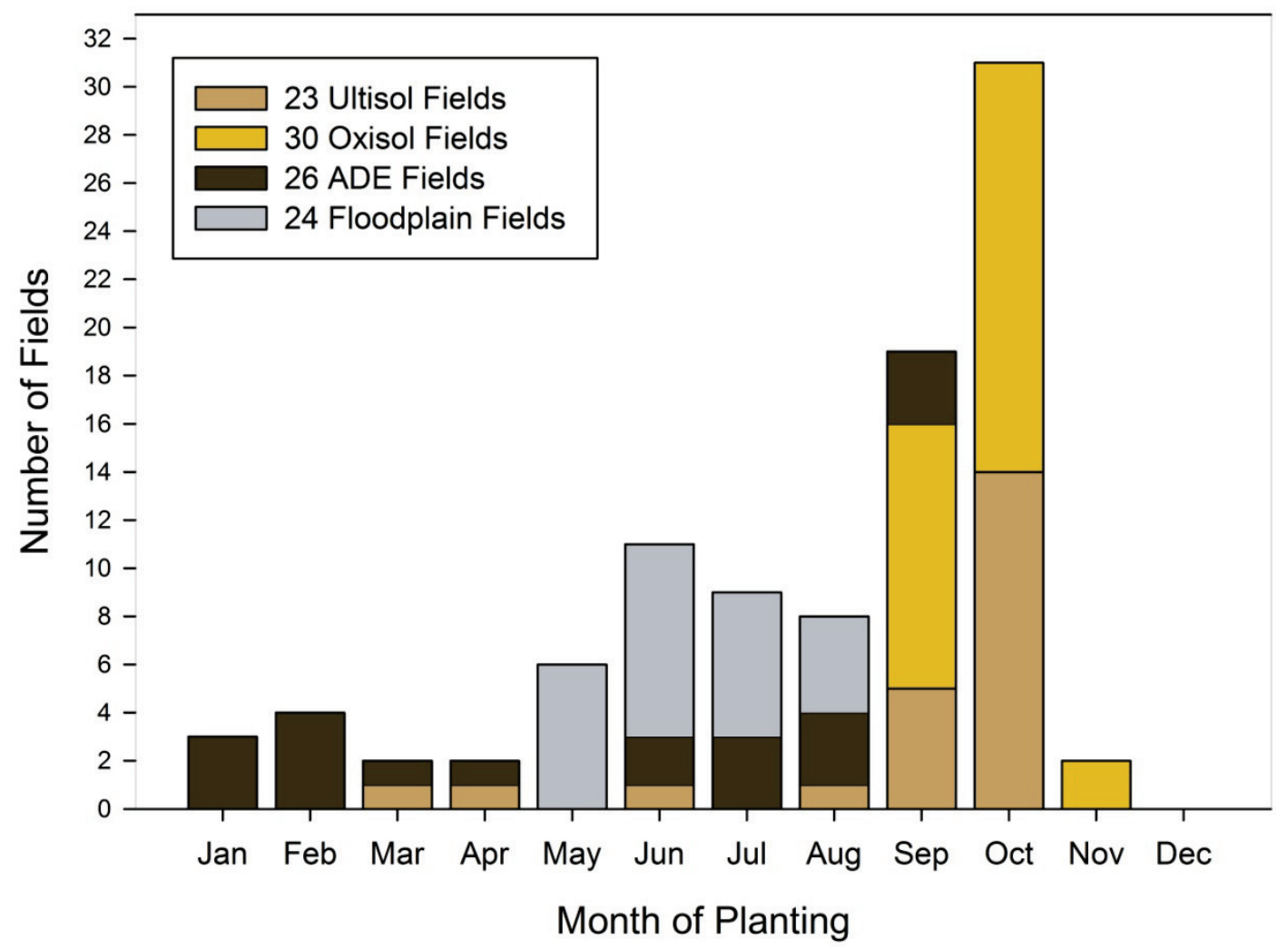

\section{Conclusion: Are Ecological Limitations on Bitter Manioc Cultivation Real or Imagined?}

Bitter manioc cultivation in fertile soils (floodplain and ADE) by Caboclos along the Middle Madeira River tends to be characterised by intensive short-cycled swidden-fallow systems with smaller fields (around $0.5 \mathrm{ha}$ ), shorter fallows (0-6 years), and a predominance of what locals refer to as "weak" landraces (low starch fast maturing, harvested 5-12 months after planting). The genetic traits of weak landraces make them well adapted to swidden cultivation in richer landscapes: they are fast maturing and yield well in fertile soils, though they exhibit lower starch content. Bitter manioc cultivation in infertile soils (Oxisols and Ultisols) along the middle Madeira River is characterised by 
more extensive long-cycled swidden-fallow systems with larger fields (around $1 \mathrm{ha}$ ), longer fallows (over 10 years) and a predominance of what locals refer to as "strong" landraces (high starch, slow maturing, harvested 1-3 years after planting). The genetic traits of strong landraces similarly make them well adapted to long fallow shifting cultivation. They are slow maturing with a high starch content and yield well in the highly leached acid soils of low fertility that are typical of the terra firme in the lowland Neotropics.

On the middle Madeira River the adaptation of manioc cultivation systems to different ecological contexts is also reflected in the local theory of strong and weak manioc, which essentially refers to the suitability of certain genetic characteristics to particular ecological scenarios (soil fertility, fallow ages, flood regime). Farmers noted that when strong manioc is planted in ADE, it may over-produce stems and leaves at the expense of tuberous roots. This local knowledge shows that any poor performance of bitter manioc on fertile soils may be the result of planting the wrong landraces, rather than any inherent ecological limitation.

The bitter manioc cultivation systems described in this article are the outcome of the agency and creativity of Amazonian peoples in relation to the affordances of different soil types and the historical ecology of landscapes in which they are situated. The diversity of these bitter manioc cultivation systems (landraces, fallow periods, soils) supports the hypothesis that, far from being constrained by them, local farmers have adapted bitter manioc cultivation to the affordances of different ecological contexts. This diversity in bitter manioc cultivation exists both at genetic (the variety and variability of landraces) and systemic (e.g., fallow lengths, cropping periods and associated knowledge and practice) levels.

The importance of bitter manioc to Caboclo subsistence is the driving force behind the emergence of these different manioc cultivation systems in different soil types, including ADE, and the knowledge associated with them. The presence of productive and intensive (faster maturing landraces, shorter fallows, shorter cropping periods) bitter manioc cultivation on ADE and floodplain soils along the middle Madeira River demonstrates that the cultivation of bitter manioc on these soils would have been possible in the pre-Columbian period. The findings presented here have implications for theoretical models of social development in the Amazonia. They undermine Roosevelt's claim that sustained yield intensive cultivation of major Amazonian tropical forest soils is not possible with aboriginal methods. The ADE and floodplain cultivation observed on the middle Madeira River is analogous to Denevan's model of simultaneous terra-firme/floodplain cultivation. This would support the notion that large and sedentary chiefdoms could have been supported by bitter manioc cultivation in ADE and floodplain soils in the late pre-Columbian period [65-68].

\section{Acknowledgements}

This paper draws on aspects of my doctoral research, funded by the Leverhulme Trust (Grant F/00 230/W), under the auspices of a scientific expedition (EXC 022/05) granted by the Brazilian National Research Council (CNPQ). This paper has benefited from discussions with Charles R. Clement, William Denevan, Manuel Arroyo-Kalin, André Junqueira, Eduardo Neves, Doyle McKey and Bill Woods. I thank Charles R. Clement, Doyle McKey, Luke Parry and three anonymous reviewers for their constructive criticism of previous drafts. I would also like to thank the editor of this special issue, 
William Balée, for his invitation to contribute, and for commenting on an earlier draft. I alone am responsible for any errors in this paper.

\section{References}

1. Heckenberger, M.J. Manioc agriculture and sedentism in Amazonia: the Upper Xingu example. Antiquity 1998, 72, 633-648.

2. Oliver, J.R. The archaeology of forest foraging and agricultural production in Amazonia. In Unknown Amazon. Culture in Nature in Ancient Brazil, 1st ed.; McEwan, C., Barreto, C., Neves, E.G., Eds.; The British Museum Press: London, UK, 2001; pp. 50-85.

3. Lathrap, D.W. The Upper Amazon; Thames \& Hudson: Southampton, UK, 1970.

4. Clement, C.R.; Cristo-Araújo, M.; d'Eeckenbrugge, G.C.; Pereira, A.A.; Picanço-Rodrigues, D. Origin and Domestication of Native Amazonian Crops. Diversity 2010, 2, 72-106.

5. Arroyo-Kalin, M. The Amazonian Formative: Crop Domestication and Anthropogenic Soils. Diversity 2010, 2, 473-504.

6. Meggers, B.J. Amazonia. Man and Culture in a Counterfeit Paradise. Revised Edition; Smithsonian Institution Press: Washington, DC, USA, 1996.

7. McKey, D.; Beckerman, S. Chemical ecology, plant evolution, and the evolution of traditional manioc cultivation systems. In Tropical Forests, People and Food. Biocultural Interactions and Applications to Development; Hladik, C.M., Hladik, A., Linares, O.F., Pagezy, H., Semple, A., Hadley, M., Eds.; UNESCO, Parthenon: Paris, France, 1993; pp. 83-112.

8. McKey, D.; Cavagnaro, T.R.; Cliff, J.; Gleadow, R. Chemical ecology in coupled human and natural systems: people, manioc, multitrophic interactions and global change. Chemoecology 2010, in press.

9. Adams, C.; Murrieta, R.; Siqueira, A.; Neves, W.; Sanches, R. Bread of the Land: The Invisibility of Manioc in the Amazon. In Amazon Peasant Societies in a Changing Environment: Political Ecology, Invisibility and Modernity in the Rainforest, Adams, A., Murrieta, R., Neves, W., Harris, M., Eds.; Springer: Berlin, Germany, 2009; pp. 281-306.

10. Emperaire, L. Elementos de discussão sobre a conservação da agrobiodiversidade: o exemplo da mandioca (Manihot esculenta Crantz) na Amazônia brasileira. In Biodiversidade da Amazônia, Capobianco, J.P., Ed.; Estação Liberdade-ISA: São Paulo, Brazil, 2001; pp. 225-234.

11. Olsen, K.M. Population history of Manihot esculenta (Euphorbiaceae) inferred from nuclear DNA sequences. Molecular Ecology 2002, 11, 901-911.

12. Olsen, K.M.; Schaal, B.A. DNA Sequence data and inferences on cassava's origin of domestication. In Documenting Domestication: New Genetic and Archaeological Paradigms, Zeder, M.A., Bradley, D.G., Emshwiller, E., Smith, B.D., Eds.; University of California Press: Berkeley, CA, USA, 2006; pp. 123-132.

13. Steward, J.H. Handbook of South American Indians. Volume 3: The Tropical Forest Tribes; Bulletin 143, Bureau of American Ethnology, Smithsonian Institution: Washington, DC, USA, 1948.

14. Steward, J.H.; Faron, L.C. Native Peoples of South America; McGraw-Hill: New York, NY, USA, 1959. 
15. Hames, R.B.; Vickers, W.T. Introduction. In Adaptive Responses of Native Amazonians, Hames, R.B., Vickers, W.T., Eds.; Academic Press: New York, NY, USA, 1983; pp. 1-26.

16. Meggers, B.J. Environmental Limitation on the Development of Culture. Amer. Anthropol. 1954, $56,801-824$.

17. Meggers, B.J.; Evans, E. Archaeological Investigations at the Mouth of the Amazon; Smithsonian Institution, Bureau of American Ethnology, Bulletin 167: Washington, DC, USA, 1957.

18. Carneiro, R.L. The cultivation of manioc among the Kuikuru of the Upper Xingu. In Adaptive Responses of Native Amazonians, Hames, R.B., Vickers, W.T., Eds.; Academic Press: New York, NY, USA, 1983; pp. 65-112.

19. Heckenberger, M.J. Biocultural Diversity in the Southern Amazon. Diversity 2010, 2, 1-16.

20. Heckenberger, M.J. The Ecology of Power: Culture, Place and Personhood in the Southern Amazon AD 1000-2000; Routledge: London, UK, 2005.

21. Heckenberger, M.J.; Kuikuro, A.; Kuikuro, U.T.; Russell, J.C.; Schmidt, M.; Fausto, C.; Franchetto, B. Amazonia 1492: Pristine forest or cultural parkland? Science 2003, 301, 1710-1714.

22. Heckenberger, M.J.; Russell, J.C.; Fausto, C.; Toney, J.R.; Schmidt, M.J.; Pereira, E.; Franchetto, B.; Kuikuro, A. Pre-Columbian urbanism, anthropogenic landscapes, and the future of the Amazon. Science 2008, 321, 1214-1217.

23. Heckenberger, M.J.; Russell, J.C.; Toney, J.R.; Schmidt, M.J. The legacy of cultural landscapes in the Brazilian Amazon: implications for biodiversity. Phil. Trans. Roy. Soc. B-Biol. Sci. 2007, 362, 197-208.

24. Junk, W.J.; Furch, K. The physical and chemical properties of Amazonian waters and their relationships with the biota. In Key Environments: Amazonia, Prance, G.T., Lovejoy, T.E., Eds.; Pergamon Press: Oxford, UK, 1985; pp. 3-17.

25. Sioli, H. The Amazon and its main affluents: hydrography, morphology of the river courses, and river types. In The Amazon: Limnology and Landscape Ecology of a Mighty Tropical River and Its Basin, Sioli, H., Ed.; Junk Publishers: Dordrecht, Germany, 1984; pp. 127-165.

26. Neves, E.G. Ecology, ceramic chronology and distribution, long-term history, and political change in the Amazonian floodplain. In Handbook of South American Archaeology, Silverman, H., Isbell, W.H., Eds.; Springer: New York, NY, USA, 2008; pp. 359-403.

27. Roosevelt, A.C. The development of prehistoric complex societies: Amazonia, a tropical forest. In Complex Polities in the Ancient Tropical World, Bacus, E.A., Lucero, L.J., Eds.; American Anthropological Association: Arlington, VA, USA, 1999; pp. 13-33.

28. Roosevelt, A.C. The lower Amazon: a dynamic human habitat. In Imperfect Balance: Landscape Transformations in the Precolumbian Americas, 1st ed.; Lentz, D.L., Ed.; Columbia University Press: New York, NY, USA, 2000; pp. 455-491.

29. Heckenberger, M.J.; Petersen, J.B.; Neves, E.G. Village size and permanence in Amazonia: two archaeological examples from Brazil. Latin American Antiquity 1999, 10, 353-376. 
30. Neves, E.G.; Arroyo-Kalin, M.; Bartone, R.N.; Castro M.W.M.; Costa, F.W.S.; Lima, H.P.; Lima, M.N.; Moraes, C.P.; Py-Daniel, A.R.; Rebellato, L.; Silva, C.A.; Tamanaha, E.K.; Woods, W.I. Site reoccupation and population growth in the late first millenium AD in the Central Amazon. Unpublished Manuscript.

31. Neves, E.G.; Petersen, J.B. The political economy of pre-Columbian Amerindians: Landscape transformations in Central Amazonia. In Time and Complexity in Historical Ecology: Studies in the Neotropical Lowlands, Balée, W., Erickson, C.L., Eds.; Columbia University Press: New York, NY, USA, 2006; pp. 279-309.

32. Petersen, J.B.; Neves, E.G.; Heckenberger, M.J. Gift from the past: terra preta and prehistoric occupation in Amazonia. In Unknown Amazon. Culture in Nature in Ancient Brazil, 1st ed.; McEwan, C., Barreto, C., Neves, E.G., Eds.; The British Museum Press: London, UK, 2001; pp. 86-107.

33. Rebellato, L.; Woods, W.I.; Neves, E.G. Pre-Columbian settlement dynamics in the Central Amazon. In Amazonian Dark Earths: Wim Sombroek's Vision, Woods, W.I., Teixeira, W.G., Lehmann, J., Steiner, C., WinklerPrins, A.M.G.A., Rebellato, L., Eds.; Springer: Berlin, Germany, 2009; pp. 15-31.

34. Roosevelt, A.C. Parmana: Prehistoric Maize and Manioc Subsistence along the Amazon and Orinoco; Academic Press: New York, NY, USA, 1980.

35. Ohly, J.; Junk, W. Multiple uses of central Amazon floodplains: reconciling ecological conditions, requirements for environmental protection, and socioeconomic needs. In Varzea: Diversity, development and conservation of Amazonias's whitewater floodplains, Padoch, C., Ayres, J.M., Pinedo-Vasquez, M., Henderson, A., Eds.; New York Botanical Garden: New York, NY, USA, 1999; pp. 283-299.

36. Moran, E. Models of Native and Folk Adaptation in the Amazon. In Advances in Economic Botany, Posey, D., Balée, W., Eds.; New York Botanical Garden: Bronx, New York, NY, USA, 1989; pp. 22-29.

37. Boster, J.S. Classification, cultivation and selection of Aguaruna cultivars of Manihot esculenta (Euphorbiaceae). Advan. Econ. Bot. 1984, 1, 34-47.

38. Chernela, J.M. Os cultivares de mandioca na área do Uaupés (Tukano). In Suma Etnológica Brasileira, 2nd ed.; Ribeiro, D., Ed.; Vozes: Petrópolis, Brazil, 1987; pp. 151-158.

39. Elias, M.; Rival, L.; McKey, D. Perception and management of cassava (Manihot esculenta Crantz) diversity among Makushi Amerindians of Guyana (South America). J. Ethnobiology 2000, 20, 239-265.

40. Wilson, W.M.; Dufour, D.L. Why "bitter" cassava? Productivity of "bitter" and "sweet" cassava in a Tukanoan Indian settlement in the northwest Amazon. Econo. Bot. 2002, 56, 49-57.

41. Carneiro, R.L. Slash-and-burn cultivation among the Kuikuru and its implications for Cultural Development in the Amazon basin. In The Evolution of Horticultural Systems in Native South America, Causes and Consequences. Anthropológica Supplement Publication No. 2, Wilbert, J., Ed.; Editorial Sucre: Caracas, Venezuela, 1961; pp. 122-132.

42. Carneiro, R.L. Slash-and-burn agriculture: a closer look at its implications for settlement patterns. In Men and Cultures, Wallace, A.F.C., Ed.; University of Pennsylvania Press: Philadelphia, PA, USA, 1961; pp. 229-234. 
43. Heckler, S.; Zent, S. Piaroa Manioc Varietals: Hyperdiversity or Social Currency? Human Ecology 2008, 36, 679-697.

44. Wilson, W.M.; Dufour, D.L. Ethnobotanical evidence for cultivar selection among the Tukanoans: Manioc (Manihot esculenta Crantz) in the Northwest Amazon. Culture Agr. 2006, 28, 122-130.

45. Balée, W. People of the fallow: a historical ecology of foraging in lowland South America. In Conservation of Neotropical Forests: Working from Traditional Resource Use; Redford, K.H., Padoch, C., Eds.; Columbia University Press: New York, NY, USA, 1992; pp. 35-46.

46. Rival, L. Trekking Through History: The Huaorani of Amazonian Ecuador; Columbia University Press: New York, NY, USA, 2002.

47. Fraser, J.A. Amazonian Dark Earths and Caboclo Subsistence on the Middle Madeira River, Brazil; Unpublished Dphil Thesis, University of Sussex, Brighton, UK, 2009.

48. Fraser, J.A.; Cardoso, T.; Junqueira, A.B.; Falcão, N.; Clement, C.R. Historical ecology and dark earths in whitewater and blackwater landscapes: comparing the Middle Madeira and Lower Negro rivers. In Amazonian Dark Earths: Wim Sombroek's Vision, Woods, W.I., Teixeira, W.G., Lehmann, J., Steiner, C., WinklerPrins, A.M.G.A., Rebellato, L., Eds.; Springer: Berlin, Germany, 2009; pp. 229-264.

49. Amazonian Dark Earths. Origins, Properties and Management, Lehmann, J., Kern, D.C., Glaser, B., Woods, W., Eds.; Kluwer Academic Publishers: Dordrecht, Germany, 2003.

50. Amazonian Dark Earths: Explorations in Space and Time; Glaser, B., Woods, W.I., Eds.; Springer: Berlin, Germany, 2004.

51. Amazonian Dark Earths: Wim Sombroek's Vision; Woods, W.I., Teixeira, W.G., Lehmann, J., Steiner, C., WinklerPrins, A.M.G.A., Rebellato, L., Eds.; Springer: Berlin, Germany, 2009.

52. Neves, E.G.; Petersen, J.; Bartone, R.; da Silva, C.A. Historical and socio-cultural origins of Amazonian Dark Earths. In Amazonian Dark Earths: Origin, Properties, Management, Lehmann, J., Kern, D.C., Glaser, B., Woods, W., Eds.; Kluwer Academic Publishers: Dordrecht, Germany, 2003; pp. 29-50.

53. Neves, E.G. El Formativo que nunca terminó: La larga historia de estabilidad en las ocupaciones humanas de la Amazonía central. Boletín de Arqueología PUCP 2007, 11, 117-142.

54. Hecht, S.B. Indigenous soil management and the creation of Amazonian Dark Earths: implications of Kayapó practices. In Amazonian Dark Earths: Origin, Properties, Management, Lehmann, J., Kern, D.C., Glaser, B., Woods, W., Eds.; Kluwer Academic Publishers: Dordrecht, 2003; pp. 355-372.

55. Schmidt, M.J. Historical Landscapes in the Neotropics: A Model for Pre-Historical Anthrosol (Terra Preta) Formation in the Upper Xingu; Conference paper at International Encounter of Amazonian Archaeology (EIAA) Belem, Brazil, 2008. 
56. WinklerPrins, A.M.G.A. Sweep and Char and the Creation of Amazonian Dark Earths in Homegardens. In Amazonian Dark Earths: Wim Sombroek's Vision, Woods, W.I., Teixeira, W.G., Lehmann, J., Steiner, C., WinklerPrins, A.M.G.A., Rebellato, L., Eds.; Springer: Dordrecht, Germany, 2009; pp. 205-210.

57. Steiner, C.; Teixeira, W.G.; Woods, W.I.; Zech, W. Indigenous Knowledge about Terra Preta Formation. In Amazonian Dark Earths: Wim Sombroek's Vision, Woods, W.I., Teixeira, W.G., Lehmann, J., Steiner, C., WinklerPrins, A.M.G.A., Rebellato, L., Eds.; Springer: Berlin, Germany, 2009; pp. 193-204.

58. Schmidt, M.J. Reconstructing Tropical Nature: Prehistoric and Modern Anthrosols (Terra Preta) in the Amazon Rainforest, Upper Xingu River, Brazil; Unpublished PhD Thesis, University of Florida, FL, USA, 2010.

59. Lehmann, J.; Joseph, S. Biochar for Environmental Management: Science and Technology; Earthscan: London, UK, 2009.

60. Glaser, B.; Guggenberger, G.; Zech, W.; Ruivo, M.d.L. Soil Organic Mater Stability in Amazonian Dark Earths. In Amazonian Dark Earths. Origins, Properties and Management, Lehmann, J., Kern, D., Glaser, B., Woods, W., Eds.; Kluwer Academic Publishers: Dordrecht, 2003; pp. 141-158.

61. Lehmann, J.; da Silva, J.P.; Steiner, C.; Nehls, T.; Zech, W.; Glaser, B. Nutrient availability and leaching in an archaeological Anthrosol and a Ferralsol of the Central Amazon basin: fertilizer, manure and charcoal amendments. Plant Soil 2003, 343-357.

62. Lehmann, J.; Kern, D.C.; German, L.; McCann, J.; Martins, G.C.; Moreira, A. Soil fertility and production potential. In Amazonian Dark Earths: Origin, Properties, Management, Lehmann, J., Kern, D.C., Glaser, B., Woods, W.I., Eds.; Kluwer: Dortrecht, 2003; pp. 105-124.

63. Kämpf, N.; Woods, W.I.; Sombroek, W.G.; Kern, D.C.; Cunha, T.J.F. Classification of Amazonian Dark Earths and other ancient anthropic soils. In Amazonian Dark Earths. Origins, Properties and Management, Lehmann, J., Kern, D., Glaser, B., Woods, W., Eds.; Kluwer Academic Publishers Press: Dordrecht, 2003; pp. 77-102.

64. Woods, W.I.; McCann, J.M. The anthropogenic origin and persistence of Amazonian dark earths. Yearbook, Conference of Latin Americanist Geographers 1999, 25, 7-14.

65. Denevan, W.M. Cultivated landscapes of Native Amazonia and the Andes; Oxford University Press: Oxford, UK, 2001.

66. Denevan, W.M. A bluff model of riverine settlement in prehistoric Amazonia. Ann. Assn. Amer. Geogr. 1996, 86, 654-681.

67. Denevan, W.M. Semi-intensive pre-European cultivation and the origins of Anthropogenic Dark Earths in Amazonia. In Amazonian Dark Earths: Explorations in Space and Time, Glaser, B., Woods, W.I., Eds.; Springer: Berlin, Germany, 2004; pp. 135-143.

68. Denevan, W.M. Pre-European forest cultivation in Amazonia. In Time and Complexity in Historical Ecology: Studies in the Neotropical Lowlands, Balée, W., Erickson, C., Eds.; Columbia University Press: New York, NY, USA, 2006; pp. 153-163.

69. Stahl, P.W. Paradigms in Paradise: revising standard Amazonian Prehistory. Rev. Archaeolo. 2002, 23, 39-51. 
70. Schmidt, M.J. Farming and Patterns of Agrobiodiversity on the Amazon Floodplain in the Vicinity of Mamiraua, Amazonas, Brazil; Unpublished Master's Thesis, University of Florida, FL, USA, 2003.

71. Pereira, K.J.C. Agricultura tradicional e manejo da agrobiodiversidade na Amazônia Central: Um estudo de caso nos roçados de mandioca das Reservas de Desenvolvimento Sustentável Amanã e Mamirauá, Amazonas; Unpublished PhD Thesis, University of São Paulo, São Paulo, Brazil, 2008.

72. German, L.A. The Dynamics of Terra Preta: An Integrated Study of Human-Environmental Interaction in a Nutrient-Poor Amazonian Ecosystem; Unpublished $\mathrm{PhD}$ Thesis, University of Georgia, Athens, GA, USA, 2001.

73. German, L.A. Ethnoscientific understandings of Amazonian Dark Earths. In Amazonian Dark Earths: Origin, Properties and Management, Lehmann, J., Kern, D., Glaser, B., Woods, W.I., Eds.; Kluwer Academic Publishers: Dordrecht, 2003; pp. 179-201.

74. German, L.A. Historical contingencies in the coevolution of environment and livelihood: contributions to the debate on Amazonian Black Earth. Geoderma 2003, 111, 307-331.

75. German, L.A. Ecological Praxis and Blackwater Ecosystems: A Case Study from the Brazilian Amazon. Human Ecology 2004, 32, 653-683.

76. Hiraoka, M.; Yamamoto, S.; Matsumoto, E.; Nakamura, S.; Falesi, I.; Baena, A. Contemporary use and management of Amazonian Dark Earths. In Amazonian Dark Earths: Origin, Properties, and Management, Lehmann, J., Kern, D., Glaser, B., Woods, W., Eds.; Kluwer Academic Publishers: Dordrecht, 2003; pp. 387-406.

77. McCann, J.M. Subsidy from culture: anthropogenic soils and vegetation in Tapajônia, Brazilian Amazonia. Unpublished PhD Thesis, University of Wisconsin-Madison, WI, USA, 2004.

78. Sillitoe, P. Ethnobiology and applied anthropology: rapprochement of the academic with the practical. J. Roy. Anthropol. Inst. 2006, N.S., 119-142.

79. Adams, C.; Murrieta, R.; Neves, W.; Harris, M. Amazon Peasant Societies in a Changing Environment: Political Ecology, Invisibility and Modernity in the Rainforest; Springer: New York, NY, USA, 2009; p. 360.

80. Smith, N.J.H. The Amazon River Forest: A Natural History of Plants, Animals, and People; Oxford University Press: Oxford, UK, 1999.

81. Fraser, J.A.; Clement, C.R. Dark Earths and Manioc Cultivation in Central Amazonia: A Window on Pre-Colombian Agricultural Systems? Boletim do Museu Paraense Emílio Goeldi. Ciências Humanas. 2008, 3, 175-194.

(C) 2010 by the author; licensee Molecular Diversity Preservation International, Basel, Switzerland. This article is an open-access article distributed under the terms and conditions of the Creative Commons Attribution license (http://creativecommons.org/licenses/by/3.0/). 